\title{
A letra $Z$
}

Vilma Arêas

Não se sabe se a resposta de seu filho mais novo chegou a tempo. A questão era específica, mas talvez o silêncio fosse causado pela estranheza da dúvida e da situação que a atormentava. Não é raro os mais moços desconfiarem da capacidade de raciocínio dos idosos, e ele deve ter levado em conta a idade da mãe. Se realmente respondeu serviu de consolo a Zeta, ou demonstração de afeto. Quanto à questão, ela já a havia resolvido e da forma mais extraordinária, segundo penso. Atravessara a rua naquele dia com o passo vacilante motivado pela doença. No consultório me dirigiu um discurso entrecortado mas candente, afirmando que encontrara a solução, a única possível. Era preciso libertar-se da piedade. Isso era tudo. No primeiro momento eu não soube o que responder e comecei a conjecturar se a resposta esperada chegara ou não. Porém meses depois Zeta já não estava em condições de ler coisa alguma, pois agonizava. Um quadro de sofrimento prolongado costuma manter qualquer pessoa à distância. Doenças incuráveis e o cheiro de velhos corpos em decomposição não animam ninguém. No caso de Zeta restou-lhe a presença de um especialista higienicamente entrincheirado em sua máscara de pano. A desolação de tudo aquilo me fez lembrar por contraste a vivacidade das ponderações de Zeta tramadas durante meses a fio, o cuidado com que desembaraçava a própria memória, a responsabilidade de colocar cada coisa em seu lugar no tempo adequado. Considerei que diante de tanto empenho os problemas da sociologia médica eram mais fáceis de resolver. Ninguém suspeita que ainda haja segredos a respeito do funcionamento do coração, dos pulmões ou da bexiga metidos dentro de um corpo. Outra coisa é a relação que mantemos com esses saberes. $\mathrm{Na}$ ocasião e por razões óbvias pensei que a questão dos odores não deixava de ter interesse. Está provado que a sensibilidade do homem moderno aos cheiros fortes foi pouco a pouco sendo aguçada pela indústria dos perfumes e dos cosméticos em contínuo aceleramento e gerando lucros que atingem as estrelas. Odores vivos de suor ou sangue dificilmente serão hoje sentidos como excitantes, conforme anotou Graciliano Ramos a respeito de sua infância, pois aromas doces e fantasias higiênicas criaram a repugnância e volatilizaram o corpo. É fácil concluir que nada disso tem ajudado os amantes e muito menos os moribundos. $\mathrm{O}$ exemplo de Freud é dos mais significativos. Durante a longa batalha que travou com o câncer de laringe que o acometeu, o mau cheiro que exalava afastou dele todas as pessoas, com exceção de Anna. Até mesmo o cão fiel recusou qualquer aproximação com o dono. São casos talvez extremos, mas podemos afiançar que na ordem dos afetos todos os casos são extremos. Além disso impossíveis de precisar. Sentimentos são apenas supostos, não podem ser pesados com exatidão, obedecem à moda, e vêm embaraçados em fórmulas convencionais que só fazem gerar desconfiança e desconforto. Nos últimos meses Zeta me confessou que além das inconveniências da idade seu corpo se comportava de maneira imprevisível, com uma lógica além de qualquer compreensão. Como se objetivamente e de forma independente o corpo trouxesse à baila situações antigas, apa- 
gando por instantes qualquer referência próxima. O mais difícil era saltar do sonho. Despertava e ficava colada nele como se uma goma a cobrisse, e se debatia enquanto tentava resolver problemas vagos ou angustiantes criados pela escuridão da noite. Ao amanhecer, quando abria os olhos, ficava longos minutos sem se orientar, desconhecendo o quarto onde dormia desde a mocidade. Mas o mais interessante era a memória física: muitas vezes levantava-se com cuidado para não despertar o homem deitado ali a seu lado na cama, ou o bebê adormecido no berço. Explicou que era uma sensação concreta, não tinha nada de sentimental. E não doía. Isto é, talvez não doesse. Também não era alucinação. A sensação estava ali, tatuada no avesso da pele. Tatuada no sexo, pensei. A presença daqueles corpos um dia ao alcance de sua mão emergia agora dos lençóis silenciosamente, como as lágrimas dos olhos. Transformados em uma espécie de mucosa materna, atingiam seus sentidos com um calor úmido, e com o cheiro inconfundível dos líquidos do corpo. Era a sensação mais forte de todas e a mais persistente. Foi nessa ocasião que começou a relembrar também a presença dos filhos moços, morando naquela mesma casa. Acompanhei meses e meses o relato daquele périplo. Uma cena específica insistia: quando eles chegavam de madrugada ouviam música, fazendo comentários em voz baixa. Não distinguia suas palavras, mas a música se desenrolava como uma fita -branca, costumava pensar- flutuando na penumbra. Na ocasião sentia uma espécie de êxtase. Hoje a mesma cena surgia, a música e o sussurro das vozes. Mas todos já estavam longe. E aqueles discos, grandes, negros, pesados atravancando o armário, o que fazer com eles? Andou em círculos pela casa, pelo quintal e pela imaginação. As sugestões se resumiam a duas: vender a um colecionador, mas onde encontrar essa gente naquele buraco de província?, ou jogar tudo fora. Por que o drama, para que tanta sentimentalidade?, chegou a observar uma amiga, diante do fervor das palavras. Zeta argumentava que os discos eram mais vivos que os gatos, e igualmente cheios de segredos. Foi nessa época que escreveu ao filho mais novo, seu preferido, pedindo uma sugestão. Tinha medo de tomar uma resolução errada e colocar tudo a perder. Não escondi a surpresa diante daquela gravidade a respeito de objetos obsoletos e ela me olhou com expressão dura. Pouco depois observei que Zeta passara a ficar muitas horas no quintal ao lado da casa, rodeando a mangueira. E olhava para os lados como se não quisesse ser vista. Era tamanha a agitação que nos encontros puxava conversa fora de propósito e cheguei a temer pela sanidade de minha tia e vizinha. Mas uma bela manhã entrou calmamente no consultório embrulhada num xale amarelo e sentou-se diante de mim. Antes que eu perguntasse qualquer coisa, disse que já encontrara a solução. Era tão simples, e tão óbvia, não sabia como não atinara logo com ela. Não podia simplesmente jogar fora os discos, ou vendê-los a qualquer pessoa. Vender aliás era a pior solução. Antes quebrar um a um com uma pedra. As coisas que se quebram têm essa vantagem. O fato é que foram vivos e estavam mortos. Todavia o problema era só dela. Os mortos não têm problemas, disse. Tivera sim muito medo de agir, assim coisa de criança, uma espécie de temor de voar ou a vertigem criada pelos espaços abertos. É que não se conformava, devia ser isso. A solução foi se libertar da piedade. Olhou séria e firme para mim. Enterrei os discos - disse calmamente - estavam mortos, precisavam ser enterrados.

jun-ag/2007 